\title{
Prevalence of dermatopathies in dogs and cats in the highland of Santa Catarina State, Brazil
}

\author{
Prevalência de dermatopatias em cães e gatos no planalto de Santa Catarina, Brasil

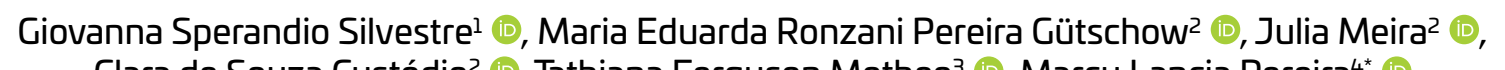 \\ Clara de Souza Custódio² (1), Tathiana Ferguson Motheo ${ }^{3}$, Marcy Lancia Pereira ${ }^{4^{*}}$
}

\begin{abstract}
This was the first study of the prevalence of skin diseases in dogs and cats in Santa Catarina. Medical records of all canine and feline patients referred to the Veterinary Clinic of the Federal University of Santa Catarina (UFSC), Curitibanos campus, were evaluated. From 2015 to 2019, 322 dogs and cats presented dermatological lesions, corresponding to $25.3 \%$ of dermatological cases. Among them, 276 (85.7\%) were dogs, and 46 (14.3\%) were cats. Definitive diagnose were obtained in $72.5 \%$ and $71.3 \%$ of canine and feline patients, respectively. Mixed breed adults were most likely to develop skin diseases. Among the primary conditions, parasitic, fungal, and bacterial diseases were the most prevalent for both species. In dogs, pulicosis, followed by pyoderma and dermatophytosis, were the major diseases encountered. Nevertheless, cats presented higher prevalence of fungal diseases, followed by parasitic and bacterial disorders. Malassezia otitis was the most prevalent, followed by pulicosis and dermatophytosis.
\end{abstract}

KEYWORDS: Skin; Feline; Canine; Southern; Occurrence.

\begin{abstract}
RESUMO: Este foi o primeiro estudo sobre prevalência de doenças cutâneas de cães e gatos em Santa Catarina. Foram avaliados os prontuários de todos os pacientes atendidos na Clínica Veterinária da UFSC, campus Curitibanos, no período de 2015 a 2019. Foram avaliados 322 animais apresentando queixas dermatológicas, o que correspondeu a 25,3\% do total de casos. Entre eles, 276 $(85,7 \%)$ eram cães e 46 (14,3\%) eram gatos. Foi possível diagnosticar $72,5 \%$ dos cães e $71,3 \%$ dos gatos. A principal faixa etária avaliada foi de adultos e a maioria dos animais era sem raça definida. Entre as principais doenças, as parasitárias, fúngicas e bacterianas foram as mais prevalentes para ambas as espécies. Quanto às principais doenças, nos cães as mais observadas foram puliciose, seguida de pioderma e dermatofitose. Para os felinos, as doenças fúngicas foram as mais prevalentes, seguidas pelas doenças parasitárias e bacterianas. A otite por Malassezia foi a doença mais prevalente, seguida por puliciose e dermatofitose.
\end{abstract}

PALAVRAS-CHAVE: Pele; Felino; Canino; Sul; Ocorrência.

\section{INTRODUCTION}

Approximately 20 to $75 \%$ of all cases in small animal practice refers to dermatopathies (SCOTT et al., 2002). Skin alterations and diseases cause extreme discomfort, and in some cases, they can be potentially zoonotic. The diagnose can be costly and time-consuming. The long-term management can be frustrating for both clinicians and tutors, given the patient's suffering, the removal of the tutor due to the concern of possible contagion, and the anguish of not having spontaneous improvement over the days (LARSSON; LUCAS, 2016).
Prevalence studies are essential on defining the main diseases that affect animals in a specific region. Published data on the prevalence of skin alterations and diseases in southern Brazil are scarce. An extensive study regarding dermatopathies was carried out in the city of Santa Maria, Rio Grande do Sul State (SOUZA et al., 2009). However, despite the geographical proximity, Santa Catarina’s Highland presents an entirely different climate, with an average temperature of $7^{\circ} \mathrm{C}$ during the winter, which can last up to 8 months a year.

The aim of the present retrospective study was to investigate the prevalence of patients with dermatological complaints and

\footnotetext{
${ }^{1}$ Graduação em Medicina Veterinária, Centro de Ciências Rurais, campus de Curitibanos, Universidade Federal de Santa Catarina (UFSC), Curitibanos/SC, Brasil ${ }^{2}$ Médica Veterinária autônoma

${ }^{3}$ Colaboradora do programa de pós-graduação em Ciência Animal, Universidade Federal de Mato Grosso (UFMT), Cuiabá, MT, Brasil

${ }^{4}$ Coordenadoria Especial de Biociências e Saúde Única, Centro de Ciências Rurais, campus de Curitibanos, Universidade Federal de Santa Catarina (UFSC), Curitibanos, SC, Brasil.

*Corresponding author: marcy.pereira@ufsc.br

Received: 01/07/2020. Accepted: 04/12/2020
} 
skin diseases attended at the Veterinary Clinic of the Federal University of Santa Catarina, Curitibanos campus, Brazil.

\section{MATERIAL AND METHODS}

This study was conducted following the standards of animal use and experimentation and approved by the Animal Ethics Committee (CEUA) from the Federal University of Santa Catarina (UFSC), under protocol number 8678120918.

Medical records of cats and dogs with skin alterations and diseases attended at the Veterinary Clinic of the UFSC, Curitibanos campus, Brazil, were analyzed from August 2015 to July 2019. Data on breed and age (pups $\leq 1$ year; adults $>1$ year and $\leq 8$ years; elderly $>8$ years) and diagnose were retrieved from the patients' records.

\section{RESULTS}

From a total of 1,271 patients, 322 dogs and cats presented dermatological lesions, corresponding to $25.3 \%$ of dermatological cases. Two hundred and seventy-six patients (85.7\%) were dogs, and forty-six (14.3\%) were cats. In dogs, most of the patients were adults (57.3\%), followed by pups (21.7\%) and elderly (21\%). Similarly, feline patients showed a higher prevalence among adults (57.3\%), followed by kittens $(32.6 \%)$ and elderly $(8.7 \%)$. For both species, mixed breed patients were more likely to develop dermatopathies $(63.4 \%$ of dogs and $95.7 \%$ of cats) compared to pure breeds (Table 1 ).

Among 276 dogs and 46 cats, 200 (72.5\%) dogs and 33 (71.7\%) cats had 234 and 25 diagnosed diseases, respectively (Table 2). Therefore, canine and feline patients presented, concomitantly, more than one type of dermatopathy. As for the remaining patients, the diagnoses were inconclusive once tutors prohibited the collection of biological material

Table 1. Frequency of canine and feline breeds with dermatopathies referred to the Veterinary Clinic of the Federal University of Santa Catarina, Brazil, from 2015 to 2019.

\begin{tabular}{l|c|c}
\hline Breed & Total & $\%$ \\
\hline Dogs & 276 & 100 \\
\hline Mixed breed & 175 & 63.4 \\
\hline Pinscher & 13 & 4.7 \\
\hline Shih Tzu & 12 & 4.3 \\
\hline Poodle & 8 & 2.9 \\
\hline Lhasa Apso & 7 & 2.5 \\
\hline Chow Chow & 6 & 2.2 \\
\hline Labrador & 6 & 2.2 \\
\hline Yorkshire & 6 & 2.2 \\
\hline Rottweiller & 4 & 1.5 \\
\hline Other breeds & 40 & 14.5 \\
\hline Cats & 46 & 100 \\
\hline Mixed breeds & 44 & 95.7 \\
\hline Persian & 2 & 4.3 \\
\hline
\end{tabular}

or neglected the follow-up period usually recommended in most of the cases.

Otitis from variable causes occurred in $42 / 234(18 \%)$ of the dermatopathies diagnosed in dogs and 11/25 (44\%) in cats (Figure 1). Considering the otopathies, the leading cause for otitis was Malassezia, corresponding to 35/42(83.3\%) and $6 / 11(54.5 \%)$ of the cases in dogs and cats, respectively. In both species, bacterial external otitis was the second most reported ear disease, with 6/42 (14.3\%) cases in dogs and 3/11 $(27.3 \%)$ cases in cats. For feline patients, parasitic otopathies caused by Notoedres cati 1/11 (9\%) and Otodectes cynotis 1/11 (9\%) were also diagnosed.

\section{DISCUSSION}

In the present study, dermatological complaints corresponded to $25.3 \%$ of the total canine and feline cases referred to clinical care. Similar findings were reported by Scherer (2015), in which skin diseases accounted for $30 \%$ of all clinical care for domestic carnivores.

Comparing species, $85.7 \%$ of the cases were dogs and $14.3 \%$ were cats. In a prevalence study carried out by Hill et al. (2006), skin diseases were also more diagnosed in dogs than in cats, corresponding to $20 \%$ and $13 \%$, respectively. According to Hoffmann (2017), felines have a more diverse microbiota compared to canines due to grooming habits and this may be related to the lower occurrence of skin diseases. In addition, Pet Brazil Institute (2019) reported that the Brazilian canine population is over two times greater than the feline population, corresponding to 54.2 million dogs versus 23.9 million cats. In our study, there was six times more canine than feline patients, which initially could be interpreted as dogs' tutors' greater attention, regarding health problems.

Most of the cases referred to our unit were feline and canine mixed breed adult patients. However, among pure breeds, Pinscher, Shih Tzu, and Poodle were the most affected by skin diseases. Interestingly, this can be explained by the high prevalence of these breeds in our region, and the fact that usually, small breed animals present an indoor lifestyle, which draws the tutor's attention to the occurrence of health problems.

In dogs, when diseases were classified by etiological groups, parasitic disorders were the leading causes, followed by fungal and bacterial infections. Notwithstanding, Hill et al. (2006) described that parasitic infestations and bacterial infections accounted for the majority of the diagnoses in dogs.

It is well known that parasitic dermatopathies are primary diseases. In our study, pulicosis presented a common occurrence in our region. This data may demonstrate the lack of parasitic control by the tutors, associated to inadequate hygienic conditions, as reported by Limongi (2013). Climatic conditions could also justify flea infestations due to the subtropical climate. Bellato et al. (2003) showed that flea infestation was the major canine skin disease in the city of Lages, which is in the same microregion of Curitibanos. 
Usually, fungal and bacterial skin diseases are secondary disorders (HALLIWELL, 2016; LOEFFLER, 2018; SCOTT et al., 1996) and often associated with parasitic and allergic dermatopathies. In this study, these diseases were highly prevalent among dogs, and when addressing skin diseases by diagnosis, the main occurrence was pulicosis $(28.3 \%)$, followed by pyoderma (16.7\%), and dermatophytosis (13.3\%), which corroborates to previous works in the literature. According to Cardoso et al. (2011), pulicosis with a cosmopolitan distribution can lead to flea allergy dermatitis, the most frequent allergic skin disease in dogs and cats. However, our data revealed a low prevalence of flea allergy dermatitis in dogs, with 3.4\%, suggesting that this condition may be strictly related to the region's climate (SOUZA et al., 2009).

Dermatophytosis includes several species of fungi, distributed to three genres, Trichophyton spp., Microsporum spp. and Epidermophyton spp. (SEGAL; FRENKEL, 2015), and its prevalence may vary according to different climatic conditions. The city of Curitibanos present subtropical and tropical climates (SÁ, 1993) characterized by high temperatures and humidity (LOPES; DANTAS, 2016), which favors the occurrence of this condition. Similar to the described for canine skin diseases, in cats, fungal infections were the most prevalent, followed by parasitic and bacterial disorders. Malassezia otitis was the most prevalent disease, followed by pulicosis and dermatophytosis. As described by Angus (2004) and
Carfachia et al. (2005), in our study, auricular malasseziosis was considered the paramount among otitis, corresponding over to $50 \%$ of diagnoses for cats and dogs.

The true prevalence of dermatophytosis in cats is unknown once it is not a reportable disease and false-positive results are common due to fomite carriage (MORIELLO, 2016). Therefore, all prevalence studies must be analyzed with scrutiny to ensure well-interpreted test results that should be associated with clinical signs, and other confirmatory testing for definitive diagnoses. In our study, all cats presented with dermatophytosis had clinical signs and were confirmed by cytological and/or mycological analysis.

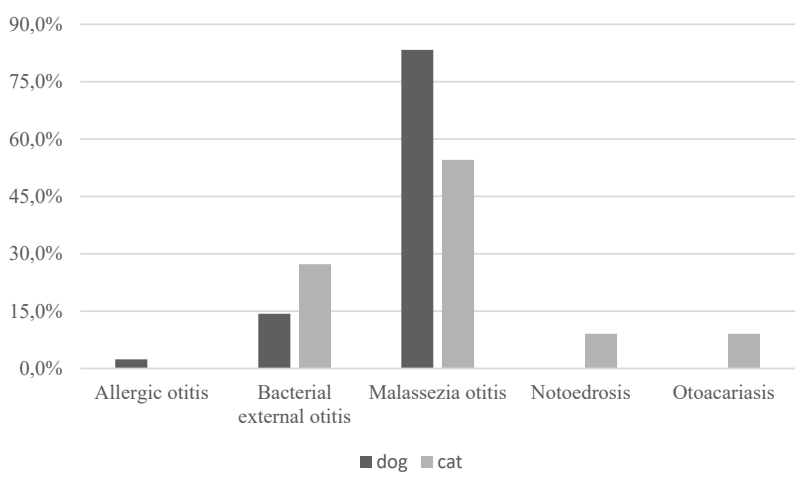

Figure 1. Distribution of canine and feline otopathies of patients evaluated at the Veterinary Clinic of Federal University of Santa Catarina, Brazil, from 2015 to 2019.

Table 2. Distribution of diagnosed dermatopathies in dogs and cats at the Veterinary Clinic of Federal University of Santa Catarina, Brazil, from 2015 to 2019.

\begin{tabular}{|c|c|c|c|}
\hline Etiological group & Diagnosed dermatopathy & Dogs & Cats \\
\hline Parasitic & $\begin{array}{c}\text { Pulicosis } \\
\text { Demodicosis } \\
\text { Myiasis } \\
\text { Sarcoptic mange } \\
\text { Otoacariasis } \\
\text { Notoedrosis } \\
\text { Pediculosis }\end{array}$ & $\begin{array}{c}66(28.3 \%) \\
12(5.1 \%) \\
12(5.1 \%) \\
7(3.0 \%)\end{array}$ & $\begin{array}{l}5(20.0 \%) \\
\\
1(4.0 \%) \\
1(4.0 \%) \\
1(4.0 \%)\end{array}$ \\
\hline Fungal & $\begin{array}{c}\text { Malassezia otitis } \\
\text { Dermatophytosis } \\
\text { Cutaneous candidiasis }\end{array}$ & $\begin{array}{c}35(15.0 \%) \\
31(13.3 \%) \\
1(0.4 \%)\end{array}$ & $\begin{array}{l}6(24.0 \%) \\
5(20.0 \%)\end{array}$ \\
\hline Bacterial & $\begin{array}{c}\text { Pyoderma } \\
\text { Bacterial external otitis }\end{array}$ & $\begin{array}{c}39(16.7 \%) \\
6(2.5 \%)\end{array}$ & $\begin{array}{l}1(4.0 \%) \\
3(12.0 \%)\end{array}$ \\
\hline Allergic & $\begin{array}{l}\text { Flea allergy dermatitis } \\
\text { Atopy } \\
\text { Allergic otitis }\end{array}$ & $\begin{array}{l}8(3.4 \%) \\
2(0.8 \%) \\
1(0.4 \%)\end{array}$ & \\
\hline Keratinization disorder & $\begin{array}{l}\text { Seborrhea } \\
\text { Oily seborrhea }\end{array}$ & $12(5.1 \%)$ & $2(8.0 \%)$ \\
\hline Endocrine & $\begin{array}{c}\text { Spontaneous } \\
\text { hyperadrenocorticism }\end{array}$ & $1(0.4 \%)$ & \\
\hline \multirow[t]{2}{*}{ Follicular dysplasia } & Color dilution alopecia & $1(0.4 \%)$ & \\
\hline & TOTAL & $\begin{array}{c}234 \\
\text { diagnostics } \\
(100 \%)\end{array}$ & $\begin{array}{c}25 \\
\text { diagnostics } \\
(100 \%)\end{array}$ \\
\hline
\end{tabular}


In the present study, only one case of endocrine skin disease was confirmed, representing $0.4 \%$ of the total diagnoses in dogs. Souza et al. (2009) reported low casuistry of endocrine skin diseases, corresponding to $2.6 \%$ of all the dermatological diagnoses. Thus, this low frequency of endocrine diseases may be attributed to the reduced number of senile dogs attended, since older animals are more susceptible to develop endocrinopathies such as hyperadrenocorticism and hypothyroidism (HALLIWELL, 1987).

As previously described, diagnosis was performed in $72.5 \%$ of the dogs and $71.3 \%$ of the cats. Similar findings were observed by Souza et al. (2009), in which $81.9 \%$ of the animals had a definitive diagnosis, and $18.1 \%$ were considered inconclusive. The diagnostic versus suspicion ratio observed in the present study was mainly influenced by structural and financial limitations. In 2015, there was a lack of some of the diagnostic resources in our institution, despite the availability of specific diagnostic tests such as bacteriological, mycological, parasitological skin examination, trichogram, and cytopathological evaluation. In addition, the collection of biological material for histopathological assessment was only implemented in 2017.

These cited limitations certainly compromised the treatment quality, considering that the Veterinary Clinic serves the middle to working poor classes of the population, which implies fewer financial conditions and commitment to general care. Besides structural limitations, it is remarkable that Curitibanos, with under 40 thousand locals, is one of the cities of the state with the lowest gross domestic product per capita (IBGE, 2017). In addition, data were collected from patients' medical records, so as a retrospective study, it is possible that details may not have been noted and medical records may not have been filled out properly.

\section{CONCLUSIONS}

This was the first prevalence study of dermatopathies of mountainous region of Santa Catarina. The casuistry of dermatology among other specialties was $25.3 \%$ between 2015 and 2019. The diagnosis was performed in $72.5 \%$ of the dogs and $71.3 \%$ of the cats. Adult and mixed breeds patients were the major group attended. Among the main diseases, parasitic, fungal, and bacterial were the most prevalent for dogs and cats. Among the main diseases, parasitic, fungal and bacterial were the most prevalent for dogs and cats. As for the main diseases, in dogs the most observed ones were pulicosis, followed by pyoderma and dermatophytosis. For felines, fungal diseases were the most prevalent, followed by parasitic and bacterial diseases. Malassezia otitis was the most prevalent, followed by pulicosis and dermatophytosis.

\section{REFERENCES}

ANCUS, J. C. Otic cytology in health and disease. Veterinary Clinics: Small Animal Practice, v. 34, p. 411-424, 2004.

BELLATO, V. et al. Ectoparasitos em Caninos do Município de Lages, Santa Catarina, Brasil. Revista Brasileira de Parasitologia Veterinária, v. 12, p. 95-98, 2003.

BRILHANTE, R. S. N. et al. High rate of Microsporum canis feline and canine dermatophytoses in Northeast Brazil: Epidemiological and diagnostic features. Mycopathologia, n. 156, p. 303-308, 2003.

CARDOSO, M. J. L. et al. Dermatopatias em cães: revisão de 257 casos. Archives of Veterinary Science, v. 16, n. 2, p. 66-74, 2011.

CARFACHIA, C. et al. Frequency, Body Distribution, and Population Size of Malassezia Species in Healthy Dogs and in Dogs with Localized Cutaneous Lesions. Journal Veterinary Diagnostic Investigation, n. 4, p. 316-322, 2005.

HALLIWELL, R.E.W. The Diagnostic Approach to Pruritus. In: WORLD CONGRESS OF VETERINARY DERMATOLOGY AND THE WORLD ASSOCIATION FOR VETERINARY DERMATOLOGY, 8., 2016. Bordeaux. Proceedings of the Continuing Education Program: Practical, Advanced, Equine, Feline, Exotic Pets. 2016.

HALLIWELL, R. E. W.; PRESTON, S. F.; NESBITT, J. G. Aspects of the immunopathogenesis of flea allergy dermatitis in dogs. Veterinary Immunology and Immunopathology, v. 17, p. 483-494, 1987.
HILL, P. B. et al. Survey of the prevalence, diagnosis and treatment of dermatological conditions in small animals in general practice. Veterinary Record, v. 158, p. 533-539, 2006.

HOFFMAN, A. R. The cutaneous ecosystem: the roles of the skin microbiome in health and its association with inflammatory skin conditions in humans and animals. Advances in Veterinary Dermatology, v. 8, p. 71-83, 2017.

IBCE. Panorama: Curitibanos, Santa Catarina. 2017. Disponível em:<https:/cidades.ibge.gov.br/brasil/sc/curitibanos/panorama>. Acesso em: 15 de abr. de 2020.

INSTITUTO PET BRASIL. Censo Pet: 139,3 milhões de animais de estimação no Brasil. São Paulo, 2019. Disponível em: <http:/ institutopetbrasil.com/imprensa/censo-pet-1393-milhoes-deanimais-de-estimacao-no-brasil/>. Acesso em: 13 de abr. de 2020.

LARSSON, C. A.; LUCAS, R. Tratado de Medicina Externa: Dermatologia Veterinária. l. ed., 2016.

LIMONGI, J. E. et al. Aspectos epidemiológicos das infestações por sifonápteros na área urbana do município de Uberlândia, Minas Gerais, 2007-2010. Epidemiologia e Serviços de Saúde, v. 22, p. 285-294, 2013.

LOEFFLER, A.; LLOYD, D. H. What has changed in canine pyoderma? A narrative review. Veterinary Journal, v. 235, p. 73-82, 2018. 
LOPES, C. A.; DANTAS, W. M. F. Dermatofitose em cães e gatos - Revisão de Literatura. In: Anais VIII SIMPAC, v. 8, p. 292-297, 2016.

MORIELLO, K. A. Dermatophytosis: Diagnosis and effective treatment "This much I know to be true". In: WORLD CONGRESS OF VETERINARY DERMATOLOCY AND THE WORLD ASSOCIATION FOR VETERINARY DERMATOLOGY, 8., 2016. Proceedings of the Continuing Education Program: Practical, Advanced, Equine, Feline, Exotic Pets. Bordeaux, 2016. p.238-245.

SÁ, L. A. C. M. Um sistema de informações geográficas para o turismo em Santa Catarina. 1993. 174 f. Dissertação (Mestrado em Engenharia Civil) - Universidade Federal de Santa Catarina, Florianópolis, 1993.
SCHERER, H. A. Estudo Retrospectivo de dermatopatias em gatos através de diagnóstico histopatológico realizados no setor de patologia veterinária da UFRCS, Porto Alegre (19902012). 2015. 33 f. Dissertação (Mestrado em Medicina Veterinária) - Universidade Federal do Rio Grande do Sul, Porto Alegre, 2015.

SCOTT, D.; MILLER, W.; GRIFFIN, C. Estructura y función de la piel. In: SCOTT, D.; MILLER, W.; GRIFFIN, C. (Ed). Dermatología En Pequeños Animales. Buenos Aires: Inter-médica, 2002. p. 1-69.

SEGAL, E.; FRENKEL, M. Dermatophyte infections in environmental contexts. Research in Microbiology, v. 166, p. 564-569, 2015.

SOUZA, T. M. et al. Prevalência das dermatopatias não-tumorais em cães do município de Santa Maria, Rio Grande do Sul (20052008). Pesquisa Veterinária Brasileira, v. 29, p. 1-6, 2009. 